\title{
Front Matter: Volume 11387
}

, "Front Matter: Volume 11387," Proc. SPIE 11387, Energy Harvesting and Storage: Materials, Devices, and Applications X, 1138701 (2 June 2020); doi: $10.1117 / 12.2572717$

SPIE. Event: SPIE Defense + Commercial Sensing, 2020, Online Only 


\section{PROCEEDINGS OF SPIE}

\section{Energy Harvesting and Storage: Materials, Devices, and Applications X}

Palani Balaya

AchyutK. Dutta

Editors

27 April - 8 May 2020

Online Only, United States

Sponsored and Published by

SPIE

Volume 11387 
The papers in this volume were part of the technical conference cited on the cover and title page. Papers were selected and subject to review by the editors and conference program committee. Some conference presentations may not be available for publication. Additional papers and presentation recordings may be available online in the SPIE Digital Library at SPIEDigita lLibrary.org.

The papers reflect the work and thoughts of the authors and are published herein as submitted. The publisher is not responsible for the validity of the information or for any outcomes resulting from reliance thereon.

Please use the following format to cite material from these proceedings:

Author(s), "Title of Paper," in Energy Harvesting and Storage: Materials, Devices, a nd Applications X, edited by Palani Balaya, Achyut K. Dutta, Proceedings of SPIE Vol. 11387 (SPIE, Bellingham, WA, 2020) Seven-digit Artic le CID Number.

ISSN: 0277-786X

ISSN: 1996-756X (electronic)

ISBN: 9781510635517

ISBN: 9781510635524 (electronic)

Published by

SPIE

P.O. Box 10, Belling ham, Washington 98227-0010 USA

Telephone +1 3606763290 (Pa cific Time)· Fax +1 3606471445

SPIE.org

Copyright $(2020$, Society of Photo-O ptic al Instrumentation Engineers.

Copying of material in this book for intemal or personal use, or for the intemal or personal use of specific clients, beyond the fair use provisions granted by the U.S. Copyright Law is a uthorized by SPIE subject to payment of copying fees. The Transactional Reporting Service base fee for this volume is $\$ 21.00$ per article (or portion thereof), which should be paid directly to the Copyright Clearance Center (CCC), 222 Rosewood Drive, Danvers, MA 01923. Payment may also be made electronically through CCC Online at copyright.com. Other copying for republication, resale, advertising or promotion, or any form of systematic or multiple reproduction of a ny material in this book is prohibited except with permission in writing from the publisher. The CCC fee code is 0277 $786 \mathrm{X} / 20 / \$ 21.00$.

Printed in the United States of America by Curran Associates, Inc., und er license from SPIE.

Publication of record for individual papers is online in the SPIE Digital Library.

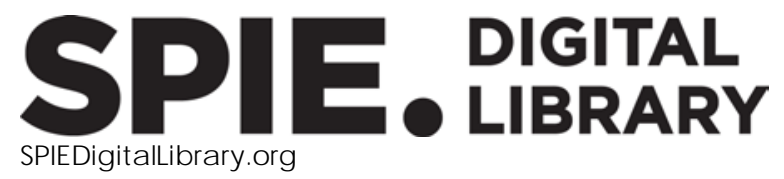

Paper Numbering: Proceedings of SPIE follow an e-First publication model. A unique citation identifier (CID) number is assigned to each article at the time of publication. Utilization of CIDs allows articles to be fully citable as soon as they are published online, and connects the same identifier to all online and print versions of the publication. SPIE uses a seven-digit CID article numbering system structured as follows:

- The first five digits correspond to the SPIE volume number.

- The last two digits indicate publication order within the volume using a Base 36 numbering system employing both numerals and letters. These two-number sets start with $00,01,02,03,04$, 05, 06, 07, 08, 09, 0A, 0B ... 0Z, followed by 10-1Z, 20-2Z, etc. The CID Number appears on each page of the manuscript. 


\section{Contents}

ENERGY STORAGE: U-ION, NA-ION AND ZNC BATIIRY

1138708 Material research for photovoltaics: from lab to market (Invited Paper) [11387-7]

ENERGY HARVESTING AND STORAGE: ADVANCED CHARACTERIZATION

11387 OD Cathode electrolyte diagnostics based on scanning probe mic roscopy (Invited Paper)

[11387-12]

ENERGY HARVESTING : THERMOEECTRIC MATRRIALS II

11387 OK Development ofa sensitized “themal” cell (Invited Paper) [11387-19]

ENERGY HARVESTING AND STORAGE: MATERIALS DESIGN

11387 ON Fourier imaging microscopy of light-emitting hybrid perovskite nanostructures (Invited Paper) [11387-22]

11387 OP Design guidelines and parametric study of nonlinear magnetic springs for vibration systems [11387-24]

\section{ENERGY HARVESTING AND STORAGE: MATERIALS AND DEVICES}

11387 OU Optical energy harvesting in a smart materials-based mic ro-actuator using a vertical multijunction PV cell [11387-30]

ENERGY HARVESTING AND STORAGE: DEVICES AND SYSTEMS

1138710 Meso-, micro-, and nano-structures induced in bismuth telluride themoelectric materials by laseradditive manufacturing [11387-35]

$1138712 \quad$ Exploning solar energy charge station for electric vehic les in Puerto Rico [11387-37]

1138714 Desalination as an energy storage altemative for nuclearpower plants: Barakah power plant as a case study [11387-40] 


\section{POSTER SESSION}

1138715 Analysis of hybrid geo-solar power plant [11387-41]

1138716 Geothemal energy use in seawaterdesalination [11387-42] 